\title{
The function of the social networks of families of hospitalized children ${ }^{a}$
}

\author{
A função das redes sociais de famílias de crianças hospitalizadas \\ La función de las redes sociales de familias de niños hospitalizados
}

Rita de Cássia Melão de Morais ${ }^{1,2}$ (1) Tania Vignuda de Souza ${ }^{1}$ (1) Isabel Cristina dos Santos Oliveira ${ }^{1}$ (1) Juliana Rezende Montenegro Medeiros de Moraes $^{1}$ (D) Elena Araújo Martinez ${ }^{3}$ (D)

Luciana de Cássia Nunes Nascimento ${ }^{4}$ (iD

1. Universidade Federal do Rio de Janeiro, Escola de Enfermagem Anna Nery.

Rio de Janeiro, RJ, Brasil.

2. Universidade Federal de Rondônia

Departamento de Enfermagem.

Porto Velho, RO, Brasil.

3. Fundação Oswaldo Cruz, Instituto Nacional Fernandes Figueira. Rio de Janeiro, RJ, Brasil. 4. Universidade Federal do Espírito Santo, Departamento de Enfermagem. Vitória, ES, Brasil.
Corresponding author:

Rita de Cássia Melão de Morais.

E-mail: ritamelao@gmail.br

Submitted on $10 / 19 / 2018$.

Accepted on 04/18/2019.

DOI: 10.1590/2177-9465-EAN-2018-0311

\section{Abstract}

Objective: To analyze the role of the social network configured by the family/companion and their implications for their stay during the hospitalization of the child in the pediatric hospitalization unit. Method: Qualitative study with ten family members/ companions of hospitalized children. Data collection was done through the technique of individual interview, which occurred in the period from February to December 2015. The analysis was thematic, in light of the theoretical reference of "Social Networks" described by Lia Sanicola. Results and discussion: The main role of the social network was emotional and material support, and the main components of this network were: companion, mother, aunt and daughter, as well as nursing team, physician and other family members/companions. Final considerations and implications for the practice: It was verified that the totality of the interviewees was female, however, the husband was the most important member of the social network for the family members involved, since they perform the material/financial and emotional function. In addition, the participants consider that they are responsible for all care to the family and, in the condition in that they are, they understand it as a favor provided by the other members of the network. Identifying the composition of the social networks of family members/companions provides a better targeting of care in order to strengthen the social support received.

Keywords: Child, Hospitalized; Social Networking; Social Support; Family.

\section{Resumo}

Objetivo: Analisar a função da rede social configurada pelo familiar/acompanhante e suas implicações para sua permanência durante a hospitalização da criança na unidade de internação pediátrica. Método: Estudo de abordagem qualitativa, com dez familiares/acompanhantes de crianças hospitalizadas. A coleta de dados se deu pela técnica da entrevista individual, ocorrida no período de fevereiro a dezembro de 2015. A análise foi temática, à luz do referencial teórico de "Redes Sociais" descrito por Lia Sanicola. Resultados e discussão: A rede social teve como função principal o apoio emocional e material, e os principais componentes desta rede foram: companheiro, mãe, tia e filha, bem como equipe de enfermagem, médico e outros familiares/ acompanhantes. Considerações finais e implicações para a prática: Constatou-se que a totalidade das entrevistadas era do gênero feminino, no entanto, o marido foi o membro da rede social mais importante para os familiares participantes, pois desempenham a função material/financeira e emocional. Ainda, as participantes consideram ser de sua responsabilidade todos os cuidados à família e na condição que se encontram, entendem como um favor prestado pelos outros membros da rede. Identificar a composição das redes sociais dos familiares/acompanhantes proporciona um melhor direcionamento de cuidado, a fim de potencializar o apoio social recebido.

Palavras-chave: Criança Hospitalizada; Rede Social; Apoio Social; Família.

\section{Resumen}

Objetivo: Analizar la función de la red social configurada por el familiar/acompañante y sus implicaciones para su permanencia durante la hospitalización del niño en la unidad de internación pediátrica. Método: Estudio de abordaje cualitativo, con diez familiares/acompañantes de niños hospitalizados. La recolección de datos se dio por la técnica de la entrevista individual, ocurrida en el período de febrero a diciembre de 2015. El análisis fue temático, conforme al entendimiento del referencial teórico de "Redes Sociales" descrito por Lia Sanicola. Resultados y discusión: La red social tuvo como función principal el apoyo emocional y material, y los principales componentes de esta red fueron: compañero, madre, tía e hija, así como equipo de enfermería, médico y otros familiares/acompañantes. Consideraciones finales e implicaciones para la práctica: Se constató que la totalidad de las entrevistadas era del género femenino, sin embargo, el marido fue el miembro de la red social más importante para los familiares participantes, pues desempeñan la función material/financiera y emocional. Además, las participantes consideran ser de su responsabilidad todos los cuidados a la familia y en la condición que se encuentran, entienden como un favor prestado por los otros miembros de la red. Identificar la composición de las redes sociales de los familiares/acompañantes proporciona un mejor direccionamiento de cuidado, a fin de potenciar el apoyo social recibido.

Palabras clave: Niño Hospitalizado; Red Social; Apoyo Social; Familia. 


\section{INTRODUCTION}

In the child's hospitalization, the family needs to (re)organize to accompany it, for this purpose, it weaves social networks in order to take into account the home activities, in the care of the hospitalized child, in the work, among others. In this way, these networks are essential in the family's life that experiences the hospitalization. ${ }^{1,2}$

The social networks constitute significant resource in the care to health, and can be thought as a set of interpersonal relationships between relatives, friends, institution, among others. This way, the individual maintain its social identity, receives support, in addition to have the possibility of developing other social relationships. ${ }^{3}$

The suffering caused by the disease and hospitalization of the child affects the family balance as a whole and between each of its members, as well as the roles occupied by them, precipitating the family's breakdown. Once the activities that, previously, were performed exclusively by the mother, now they are by other members of the family, what may lead in some situations, to overload of all their activities on only one person. In this way, one cannot think about child's hospitalization unlinked from the family, since the same mobilizes itself to maintain its functioning..$^{2,4}$

The social networks have changed in its structure over time and the events, they move as a consequence of critical events ${ }^{3}$ as, for example, the disease of a child and its hospitalization.

During the child's hospitalization the social network is composed both of the family and friends, and the persons with which the relative/companion live with during its hospitalization, among them, other companions and health professionals. The relatives who construct fragile social networks (quality of the link and function) do not receive adequate support and by this reason they present major material, psychological and emotional difficulties..$^{5,6}$

The construction of a social network that provides the support during the child's hospitalization ensure the relative/ companion the attendance of some needs within and outside the hospital scenario, consequently, ensuring greater peace during its permanence with the child in the hospital. ${ }^{1,6}$

The literature points the nursing professionals as part of the network established in the hospital during the child's hospitalization, and that may contribute in a positive way to the moment of difficulty experienced in its life and of its relative, in seeking alternatives for giving them support and/or favor them in using an own network of social support. ${ }^{6}$ It is also added the support perceived, positively by the relatives/companions, received from other professionals of the hospital context who has less formal behaviors, from a reality closer to the families, kitchen assistants, cleaning assistants, among others. ${ }^{1}$

It is noted the importance of the social network knowledge of the hospitalized children's relative/companion, since it allows the health team to recognize who are and how are the individuals' bonds that constitute these support networks, which are their functions and which particularities of this relational context of the relative/companion can be triggered in order to make the support more effective. ${ }^{6}$ In this sense, this study has as object the social networks of the hospitalized children and their support functions.

The study objective was to analyze the social network function configured by the relative/companion and its implications for its stay during the child's hospitalization in the Pediatric Hospitalization Unit (UIP).

\section{METHOD}

The theoretical-methodological reference was the one of the "Social Network" described by Lia Sanicola who has a family approach and takes into consideration the family context in which the person is inserted. For acquisition data in this research we built social networks maps, however, the maps will not be presented in this article, since we will discuss the function of the social network of the participant families.

In accordance with the referential, the functions performed by the social network may be the most diversified, such as those of material/domestic nature (food, clothing and domestic assistance) and psychological (feelings of safety, belonging, identity and of recognizing). The function allows the perception of the support type provided by the network and its impact on the person, and these functions have a high networks symbolic dimension, a generator of an observation dynamics that, over time, converts itself into a gratitude and solidarity posture among the individuals, promoting the cultural significance processes. ${ }^{3}$

That is, the participant in the research as an individual who arise from a culture and has differentiated experiences, knowledges; material, emotional and psychological needs, diverse contexts, among others, influences the value and its recognizing related to the elements of this social network (primary network-persons and secondary network-institutions) and their functions.

It is a descriptive study of qualitative approach. The place of study was the PHU of a public Hospital specialized in pediatrics situated at the Rio de Janeiro city and that hospitalize children in the age group one month-12 years and that is comprised by 46 beds.

The participants were ten relatives/companions of hospitalized children and identified by the degree of relatedness to the child, followed by the alphabet letters, according to the interviews sequence. It was considered as the inclusion criterion: the relative/companion, considered the main caregiver of the child during the hospitalization, independently of the child had had previous hospitalizations or it has been its first hospitalization. Exclusion criteria: companions non- family members.

The collection data took place in a deactivated infirmary, more specifically, in the own PHU near to other infirmaries, providing not only the absence of movements of passers-by, as well as the privacy, added to the fact that the relative might be communicated rapidly, in the event of any complication with the child who, in turn, would require its presence, giving more tranquility. 
For collecting the data we built social networks maps of the participants to know its composition and the bonds established among the members. We also used the form of characterization of the participants and the semi-structured interview route which addressed the following questions: What are the people that are present in your life (relatives, neighbors, friends, colleagues and persons from associations or work) at that time of the illness and hospitalization of the child? What type of link do you have with these persons?; At some moment did you need help or did you have some difficulty to accompany the child here in the hospital? With whom or in which location (health institution, NGO, church, workplace, others) do you considered as a social support?; From the help that you received during the child's hospitalization, which you consider more important for its stay here in the hospital?

The interview took place between the researcher and the participant. The same were recorded in digital device and transcribed, in full, soon after the interview, by the own researcher. The data collection took place from February to December 2015, each interview lasted fifty minutes on average and there was no refusal for the invited participants. The number of interviews ceased when the theoretical saturation had been reached, since new elements did not occur from the interviewees' discourses, which makes the inclusion of new information is no longer relevant, because it does not change the understanding of the studied object. ${ }^{7}$

As a method for the data analysis, the thematic analysis was used, according to Minayo's precepts, ${ }^{8}$ and built the category: social support that is presented as topic of analysis called: The social support received by the relatives who accompany the hospitalized child.

The project was approved by the Research Ethics Committee with Human Beings, of the proposing and co-participating institution, with the opinion No. 938786. The participants in the study signed the Free Informed Consent Form, according to the Resolution No. 466/2012, of the National Health Council. ${ }^{9}$

\section{RESULTS}

Concerning the characterization of the ten interviewed, nine were mothers and one was great grandmother (legal responsible). In spite of the totality belonging to the female gender and they are represented in its majority by the mother, in the present study these will still called companions relatives.

The characterization of the participants in the study was composed of relative whose age group varied from 18 to 58 years. The number of children varied from one to six. As to the residence location, five resided in the city of Rio de Janeiro, four resided in other municipalities of the State and one came from Africa, but, at the moment of the data collection, it resided temporarily in the city of Rio de Janeiro for the child's health treatment.

Regarding the level of education, three had incomplete Elementary School, three had complete High School, two had complete Elementary School, one had incomplete High School and one had Higher Education on Administration.
Regarding the marital status, eight lived with her companion and two were married formally.

With regard to the medical diagnosis of the children of the interviewed relatives, most were affected by chronic diseases, such as: Arnoud Chiare syndrome (2); Diagnostic investigation (cystic fibrosis suspicion) (2); cerebral palsy (1); non-progressive chronic encephalopathy (1); West syndrome (1); Chronic Pulmonary Histoplasmosis (1); Meningoencephalitis (1); and Biliary ducts atresia (1).

Regarding the hospitalization time of the child, it ranged from 7 days to 8 months. All children had previous hospitalizations and their frequency varied from one to fourteen times.

\section{The social support received by the relatives who accompanied the hospitalized child}

This topic of analysis addresses the social support received by the relative companion of the hospitalized child regarding emotional/affective and material/domestic support for its stay in the hospital scenario and remunerated professional activity.

The deponents of the study were supported by the relatives concerning comfort and hope words, encouraging, in this manner, the stay of the relative/companion in the hospital, and, to emphasize, we cited the speeches of the Mothers A, B and E:

[...]my husband[...] he give me a lot of strength for me to stay here taking care of her ...I have telephone contact with my mother at all times [...](Mother A)

[...] each one helps the way he can, or calls or comes [...] A message they send me just makes the difference [...] She (aunt) gives me more the psychological and emotional support, she talks a lot [...] (Mãe B)

My husband, he helps me from a distance, he calls to know [...]my mother is always giving me good advices, strength, support...they (daughters) understand, perceive, sometimes, encourage me [...] (Mother E)

The main social network support of the relative/companion is the husband who is valued as the most important member of the family.

[....] of the aid that I received the one of my husband without doubt is the most important, because he is at home holding the stride, and me here. (Mãe C)

The most important aid is the one of my husband... he is always with me ... he gives me peace, love, affection [...] (Mother I)

In addition to the members of the family, primary social network, the relatives/companions referred receiving emotional support of some nursing professionals: 
The nurse $2[. .$.$] , she is very good [...]she gives me much$ emotional support, she reassures me a lot [...] (Mãe B)

The Nursing technician 5 is a great professional...is emotional, [...] he asks how are the things [...] (Mother D)

$[\ldots]$ l have a great affinity with the 5 , a nursing technician [...] It has the technique (female) 11, it's another one I like a lot [...] it's because we talk [...] they come to know, if everything is okay,[...] they give me support, they encourage me. (Great grandmother F)

The nursing technician 1 (female) went beyond of the professional [...] (Mother J)

In addition to these professionals, the medical category was also cited.

Because, in those hours we become fragile and I liked her (doctor 4) as a doctor (female), she has more affection [...] (Mother C)

He (doctor 3) gives emotional support, talk to us [...] She (doctor 1)[...] talk to me a lot and encourage breastfeeding the $G$. (Mother $\mathrm{G}$ )

[...]l consider the doctor 1 thus as a very human person [...] The doctor 2 (female) if she did not love for others she would do it anyway [...] (Mother $\mathrm{H})$

Also, two participants referred receiving emotional support from relatives/companions of other children:

We are here (bed 5) long time and one gives support to other, anything that happens, if one feels bad, the other is there on the side. (Mother $\mathrm{C}$ )

With the companion of the bed 2[...] the support is emotional, like that, a sister that I never had [...]to trust, to talk, to speak, to vent, these things [...] (Mother D)

In addition to the emotional support, other form of support reported by all participants refers to the material (financial support) received from the family and religious representative (shepherdess), with highlight to some talks:

[...]my husband buys the things of the child (male) for me [...] my mother asks me [...], if something is missing she brings [...]she (mother-in-law) always brings anything for the baby...She (aunt)[...]is something is missing [...]she brings it to med, give me present, [...]she (shepherdess) [...] ]always ask me If missing anything, then my husband brings, [...]she (sister-in-law) send present, diaper, these things[...]she (friend, the shepherds 'daughter) always send anything to the child $B[. .$.$] (Mother \mathrm{B}$ ) [...]my husband brings clothes, the things. When I say that I'm in need of money, he (brother 4) goes there and help me, he always is helping me [...]my husband is the responsible for the expenses of the house [...] (Mother D)

$[\ldots]$ but this income mine of $R \$ 400.00$ here in Brazil it's because my husband send me [...] (Mother $\mathrm{E}$ )

In the case of the mother $E$ who is temporarily in Brazil, the material support was also acquired by nurses:

[...]they gave me that cloth for cold that I'm wearing [...] Nurse 7[...] she gave me a television [...] the nurse 8 bought some small clothes for the $E$, she gave me some things for home [...] arrange me the dishes [...]and dish cloth[...] (Mother E)

Other cited sources of material support were the financial coming from the secondary network, such as the Social Assistance Organic Law (LOAS) for the children that meet the criteria to receive it; benefit of the municipal government for diaper buying; Family Allowance; and material support of a Non-Governmental Organization (ONG) and of the Church.

$[\ldots]$ lt has more the benefit of my son that is a wage. It has a municipal benefit that is $R \$ 260.00$ to buy diaper. [...] (Mother C)

The child $F$ receives the minimum wage of the illness-aid $[\ldots] l$ buy the things for him [...] (Great grandmother F)

$[\ldots] l$ receive family allowance in the value of $R \$ 156.00$ that is my only income [...] (Mother I)

[...]the ONG A[...]gives basic basket. The friend 1 made an announcement and the church help me with money [...] with which I managed to buy diaper, milk [...] (Mother E)

Still, as material support, the companions highlighted the family aid in the care of the other children who stayed at home, among other domestic activities.

[...]my husband help me in everything, washes the clothes, takes care of the house. He brings clean clothes too, because here you cannot wash[...] (Mother B)

[...]my other three children stay with the grandmother of my husband at home [...] she gives lunch to the children before going to school [...]my uncle picks up the children at school [...] (Mother C)

[...]my husband takes care of the other child [...] makes food, washes our clothes, cleans the house and work and I stay with the child $D[. .$.$] (Mother D)$ 
[...] my mother-in-law is taking care of my son (twin of the J)[...] of my house and of her son [...] sometimes she (neighbor) and my cousin (female) take the children's clothes and wash/pass and deliver to my mother-in-law [...] (Mother J)

All deponents reported having no difficulties with regard to accompany the child during the hospitalization:

[...]l have no difficulties or problems to accompany my daughter here at hospital, because I do not have any other children [...]because I can always count on my mother ... (Mother A)

I had no difficulty, because everything is already outlined, I stay with her here and my husband take care of the house and my other child [...]lf I have difficulties I count on the child D's father, always. (Mother D)

Six deponents highlighted not developing remunerated activity for having to take care of the child, as highlighted by the three deponents:

[...]l always worked at home taking care of my family and selling things, now I'm ceasing with everything, because I sell lingerie, I sold bed cloth, but now I ceased because of that boy deal [...] (Great grandmother F)

[...] when I was at home, I was working, making some savory snacks [...] because my husband is also unemployed [...] Then, due to what happened with my daughter, I ceased [...] (Mother I)

Of the ten interviewed, only two maintained a formal employment relationship:

[...] I finished my maternity leave of four months... they put me on vacation because the vacation had won [...]then it has the pregnant woman stability that corresponds to 5 months [...] they can dismiss me [...] Then, the work is some unstable [...] (Mother B)

I work in a store [...] I'm on leave for a long time, it has already 5 months [...] (Mother J)

\section{DISCUSSION}

By making an association with the age group, number of children and level of education, it is noted that of the ten participants, those who had more than two children had the incomplete elementary school, as well as were residents of Rio de Janeiro state and one came from Africa.
It is noticed that the lower the level of education, as well as those who lived outside the Capital, the greater the number of children. Still, it is emphasized that the studied scenario assists children in lower socioeconomic conditions, which may leave the relatives who accompany the hospitalized child more vulnerable and dependent on social networks and their functions.

The vulnerability may or not present a risk, depending on the relation that is established between the needs and the available resources to address it. When the harmony between challenges and resources is broken, the vulnerability arises, which may be alleviated, insofar as it gets increasing, in quantity and quality, the resource of human relations on demand. ${ }^{3}$

Excepting the hospitalized children for diagnostic investigation, it is noted that a good part of them had chronic diseases staying hospitalized for long periods, or even, re-hospitalizing quite often, which would require a social support network that could support and care of the family of that hospitalized child.

Justified by the technological evolutions that extend the survival of these children with chronic diseases, their tendency is to have frequent hospitalizations or stay for long periods in hospital for clinical treatment. ${ }^{10}$ As a consequence of this situation, the family need to rearrange to guarantee the right of the child to be accompanied at hospital and care for the other children that stay at home, as well as, to realize the domestic activities, configuring itself in a different manner from the family networks. ${ }^{11,12,13}$ Still, the family is an indispensable source of support for the mother, by means of comfort, financial aid and, in some occasions, including, of alternation in hospital. ${ }^{12}$

The primary social network, which is composed of the family plays the function of care, since it assumes the needs of all their components and that, in front of their most fragile members, mobilizes the networks solidarity. ${ }^{3}$

The totality of the support network members of the relatives/ companions was composed of the female gender, among them, the mothers, aunts and sisters, on the other hand, all participants mentioned the husband as the most present member of the family, evidencing that the configuration of the family is nuclear and the participation of the male gender, represented by the father or stepfather is becoming more and more effective.

The experience of caregiving between men and women presents differences in consequence of the different forms of socialization and roles given to them in society. The women, from small ones, are created to deal with the domestic tasks, family feeding and of the care before the illness of one of the family members..$^{13}$ Therefore, the women suffer the most changes in their daily routine due to the child's hospitalization, despite it is her option to accompany the child. ${ }^{15}$

The deponents of this study mentioned receiving, mainly, emotional and material support of their primary network, highlighting the husband in his attendance to the needs of clothing and hygiene products as well as financial support for maintaining the expenses, domestic activities and caring of the other children at home. 
In study about the social network of hospitalized children, the family as the main source of emotional support. ${ }^{14}$ Compliance, tenderness, respect, presence, orientation, support, emotional support and compassion in the relationship among the members of the family, specially between the couple, exert the effect of refreshing source of the maternal energies. ${ }^{15}$

Such articles corroborate the results of this study in that the referred social network is composed of the most significant members: husband, mother, aunt and daughter. The support received by the family network, by means of messages and talks provided positive psychological consequences to the relative/ companion. When faced with attitudes of affection, they were motivated and gained strengths for facing the difficulties arising from the child's illness and hospitalization, mainly from one relative companion, who left all his family in the country of origin.

The family bonds occupy an important space in the social networks, although the territorial mobility of the families make them physically less close, developing in persons an ability to maintain the relations at a distance, as well as of selecting, among the family bonds, the most significant relationships. The moving to another city or other country implies a separation of the network of origin, which is physically distant, but affectively present. $^{3}$

The members of the social networks of the hospitalized child's family can help in many ways, among them, carrying out domestic tasks, taking care of the children who stayed at home, offering emotional or financial support, with a view to contribute to alleviate the family's suffering and being, an effective aid. ${ }^{11,13,15}$

The health professionals were also mentioned in the secondary social network, mainly for showing tenderness, attention and sincerity in the emotional involvement, as well as the relatives/companions of other hospitalized children, for being participants of the same environment and experiencing the suffering from the child's illness and hospitalization, sympathizing and giving emotional support each other.

The social support provided by the nurses of this study extrapolated the expected as professional, since they sympathized with the material lack of some of these subjects, not limited to the professional responsibilities. However, despite mentioning these nurses as members of their social network, recognizing the emotional function, they do not recognize/valorize the material function provided by them, considering it less important.

There are several persons who offer support to the family and the individual throughout life, emphasizing those linked by bonds of consanguinity, close kinship, beyond persons without consanguineous bonds, such as friends, companions and others, ${ }^{15}$ making the relative companion more safe. ${ }^{13}$ The suffering of the relative may still be alleviated during the child's hospitalization, when it sees commitment of the health professionals during the hospitalization. ${ }^{4}$

Confirming the findings, the study with relatives/companions pointed out that the nursing is part of its support network, and can contribute positively. In some situations the nursing team is the main support source of the relative, providing emotional support, orientations, well-being and support, ${ }^{15}$ as well as, become part of its world and share expectancies and care. ${ }^{6,13}$

The relatives/companions still Interact with other companions, establish bonds of friendship and become cooperative with each other. In this relationship of solidarity, they become to recognize the suffering from others, simultaneously look forward to comfort themselves reciprocally, becoming then part of the support networks each other, in order to together go through this painful period of their children's hospitalization. ${ }^{15}$

As life continues, the networks pull away that acquired by birth, since the personal relationships differ from the family relationships. In front of an event more or less critical, such as the child's hospitalization, it arises an opportunity of consolidation of bonds already existing or the creation of new bonds. Consequently, the networks suffer important changes, to the point of being deeply modified in their composition (family, relatives and friends) and function played. ${ }^{3}$

It should be stressed that the relative/companion, who in its majority is the mother, gives up all its daily life, isolating herself in the hospital and losing part of her identity and visibility. This fact garner the attention, because they are children bearers of chronic diseases, whose demand might extend throughout the life, in front of which the participants refer no difficulty do deal with, since the network reorganizes itself before the event of the child's hospitalization.

The own members of the primary network, that is a relational unit, has a history that is built by bonds and friendship. The same is competent to interpret its needs, share them, elaborate a project that respond to them and, in a general way, solve them, that is, the network has competence to define the personal needs and produce adequate answers to the difficulties that arise. ${ }^{3}$

If on the one hand the relative/companion receives support of the primary network to stay with the child in hospital, on the other hand they allow that the other members of the family remain in their daily routine, that is, it can be stated that the support, in this case, is not a route of one-way street, but yes reciprocal, despite imperceptible by the participants.

The primary networks, more specifically the family network, of which the individuals are part, have a potential ability to attenuate the problems. The effect of the support received by a person may produce consequences for the psychological state of motivational effect, of encouraging and hope, resulting in well-being and safety. ${ }^{3}$

They also give up on their remunerated activities, be it formal or informal, to stay in the hospital dedicating exclusively to the care of the hospitalized child. Being also, the scenario of the study, a public institution, assisting children who come from underprivileged communities, it is expected that many of them obtain the aid of the Government such as: the Social Assistance Organic Law (LOAS) or Family Allowance. 
Before the critical events the network "wound" reacts in different manners. In some cases, movements that go beyond the primary network boundaries engage in it and turn to the secondary network when the networks do not have sufficient material or emotional resources to take charge of its weaker members or to protect them. ${ }^{3}$

In some cases the companion gives up the work, considering that the child at hospitalizing needs to be accompanied by a responsible person, being most of the times, the mother the indicated. ${ }^{5}$ However, the unemployment is considered a unfavorable factor, since, throughout the child's hospitalization, the family has their high expenses, because of the costs with transport, feeding, among others. ${ }^{4}$

The negative critical events, such as the loss of employment or give up the remunerated activity to accompany the hospitalized child may be related to an individual, but these effects fall on the whole network. These are events that interrupt the life of the families and the networks, determining movements, new relational positioning, true twists. Some members approach, involve themselves, give support, share the load, and take responsibilities, while others move away. ${ }^{3}$

The participants of the study that still maintain formal employment relationship, based on the Constitution, remain somehow emotionally affected, since this guarantee will finish at the end of this financial stability, however, for having the child the diagnosis of chronic disease, their expenses will continue and the same will not able to leave for a new job.

The stability of the employed pregnant woman is a right ensured by the Federal Constitution of 1988, in its article 10, item II, letter b of the Transitory Constitutional Disposition Act, in that "it is forbidden the unfair dismissal or dismissal without cause of the employed pregnant woman, since the pregnancy confirmation until five months following birth". ${ }^{16}$

There are passages in the life of people that leave important implications for the social networks configurations and, therefore, in their structure, in the functions that they exert, in the relational dynamics that is established in their interior and among networks. ${ }^{3}$

\section{FINAL CONSIDERATIONS AND IMPLICATIONS FOR PRACTICE}

It was noted that the totality of interviewees were female, however, the husband was considered the most important member of the social network for the participant relatives, since perform the material /financial and emotional function. The link of the study participants with husband/companion showed considerable solidity, favoring the relief of the family overload, mainly of the mother, because she is the main child's companion during the hospitalization.
In the social network reorganization during the child's reorganization, the relative/companion build relationships of emotional and material strengthening with other companions, with the nursing team and the secondary network, such as NGO and churches.

It is concluded that the primary social network of the participants was established as a relationship of emotional and material dependence, in that the relative/companion was attended on what that seemed to be socially unique and exclusively under their responsibility. In this case, the relatives who stay in the hospital remain confined, while those who are maintained at home aggregate more activities, as well as, are in a space which is yours (home), maintaining its autonomy, with known persons and altering little by little their routine, differently from the one who remains in the hospital.

Still, the fact that the used author as the theoretical reference of "Social Network" is social assistant and her studies be applied in the community scenario, it is noted that it is possible using the referred referential in the hospital scenario, by nurses and other health professionals, bearing in mind, the complexity and deepening of the social network studies of the hospitalized child family.

In this regard, the study aimed at both strengthening of the qualitative investigation techniques and deepening of the health intervention procedures, as well as the understanding of this reference by researchers of the health area, especially of the nursing. It consists of a relevant instrument for the understanding of the efficiency of their attitudes in the professional routine, as well as provides a broader view on the social and family experience by the individual.

As contribution of the study, the brought arguments are as follows: the health professional can build the social network map of the hospitalized children, in the sense of recognizing the social actors of their relatives in order to strengthen the significant aid in the relational context of the relative/companion and, also, identify possible members who do not relation in a beneficial way with them. It should also create spaces so that the multidisciplinary team maintain a dialogic relationship with the relative/companion in order to clarify its doubts and wishes, in addition to make the institution more welcoming.

The limitations of this study are related to the fact that although most children had chronic diseases, the results found were of only one institution, which requires, therefore, that they are not generalized or comprehensive.

In this regard, it is recommended new studies in other scenarios to know the social network of children with acute diseases or temporary hospitalization or, even, that is used other theoretical and methodological referential, in order to contribute to the hospital pediatric nursing assistance practice. 


\section{ACKNOWLEDGEMENT}

Post-Graduation Program of the School of Nursing Anna Nery of the Federal University of Rio de Janeiro

\section{REFERENCES}

1. Menezes M, Moré CLOO, Barros L. Social Networking Family of Caregivers during Hospitalization of Children. Rev Esc Enferm USP [Internet]. 2016 jun; [citado $2017 \mathrm{dez}$ 22]; 50(spe):[aprox.7 telas]. Disponível em: http://www.scielo.br/scielo.php?script=sci_ arttext\&pid=S0080-62342016001100107\&lng=en. DOI: http://dx.doi. org/10.1590/S0080-623420160000300016

2. Souza ÍP, Bellato R, Araújo LFS, Almeida KBB. Genogram and Ecomap as tools for understanding family care in chronic illness of the young. Texto Contexto Enferm [Internet]. 2016; [citado 2018 fev 21]; 25(4):[aprox.10 telas]. Disponível em: http://www.scielo.br/scielo. php?script=sci_arttext\&pid=S0104-07072016000400301\&lng=en. DOI: http://dx.doi.org/10.1590/0104-07072016001530015

3. Sanicola L. As dinâmicas de rede e o trabalho social. $2^{\mathrm{a}}$ ed. ampliada. São Paulo: Veras Editora; 2015.

4. Franck LS, Ferguson D, Fryda S, Rubin N. The Child and Family Hospital Experience: Is It Influenced by Family Accommodation?. Med Care Res Rev [Internet]. 2015 apr; [citado 2018 mar 20]; 72(4):[aprox.18 telas]. Disponível em: https://www.ncbi.nlm.nih.gov/ pmc/articles/PMC4512521/pdf/10.1177_1077558715579667.pdf DOI: 10.1177/1077558715579667

5. Morais RCM, Souza TV, Oliveira ICS. The (dis)satisfaction of the companions about their condition of staying in the pediatric ward. Esc Anna Nery Rev Enferm [Internet]. 2015 sep; [citado 2017 fev 23]; 19(3):[aprox.8 telas]. Disponível em: http://www.scielo.br/scielo. php?script=sci_arttext\&pid=S1414-81452015000300401\&lng=en DOI: http://dx.doi.org/10.5935/1414-8145.20150053

6. Morais RCM, Souza TV, Oliveira ICS, Moraes JRMM. Structure of the social network of mothers/caregivers of hospitalized children. Cogitare Enferm [Internet]. 2018; [citado 2018 fev 21]; 23(1):[aprox.9 telas]. Disponível em: http://revistas.ufpr.br/cogitare/article/view/50456 DOI: http://dx.doi.org/10.5380/ce.v23i1.50456

7. Nascimento LCN, Souza TV, Oliveira ICS, Moraes JRMM, Aguiar $\mathrm{RCB}$, Silva LF. Saturação teórica em pesquisa qualitativa: relato de experiência na entrevista com escolares. Rev Bras Enferm [Internet]. 2018 fev; [citado 2018 set 26]; 71(1):[aprox.6 telas]. Disponível em:
http://www.scielo.br/scielo.php?script=sci_arttext\&pid=S0034 71672018000100228\&lng=pt DOI: http://dx.doi.org/10.1590/00347167-2016-0616

8. Minayo MCS. O desafio do conhecimento: pesquisa qualitativa em saúde. 14ª ed. São Paulo: Hucitec; 2014.

9. Brasil. Ministério da Saúde. Conselho Nacional de Saúde. Resolução no 466. Diretrizes e normas regulamentadoras de pesquisas envolvendo seres humanos. Diário Oficial da União, Brasília (DF), 12 dez 2012.

10. Cruz CT, Zamberlan KC, Silveira A, Buboltz FL, Silva JH, Neves ET. Care to children requiring continuous and complex assistance: nursing perception. REME Rev Min Enferm [Internet]. 2017; [citado 2018 set 10];21:e1005:[aprox.7 telas]. Disponível em: http://www.reme.org.br/ artigo/detalhes/1141

11. Rumor PCF, Boehr AE. O impacto da hospitalização infantil nas rotinas das famílias monoparentais. Rev Eletr Enf [Internet]. 2013 out/dez; [citado $2017 \mathrm{dez}$ 10]; 15(4):[aprox.9 telas]. Disponível em: https:// www.fen.ufg.br/revista/v15/n4/pdf/v15n4a19.pdf DOI: http://dx.doi. org/10.5216/ree.v15i4.19546

12. Figueiredo S, Gomes I, Pennafort V, Monteiro A, Figueiredo J. Sentimentos de mães atribuídos à hospitalização de um filho. Cogitare Enferm [Internet]. 2013; [citado 2017 nov 15]; 18(3):[aprox.6 telas]. Disponível em: http://revistas.ufpr.br/cogitare/article/view/33571

13. Passos SSS, Pereira A, Nitschke RG. Routine of the family companion during hospitalization of a family member. Acta Paul Enferm [Internet]. 2015 dec; [citado 2018 set 26]; 28(6):[aprox.7 telas]. Disponível em: http://www.scielo.br/scielo.php?script=sci_arttext\&pid=S010321002015000600539\&lng=en DOI: http://dx.doi.org/10.1590/19820194201500090

14. Polita NB, Tacla MTGM. Network and social support to families of children with cerebral palsy. Esc Anna Nery [Internet]. 2014 mar; [citado 2018 jan 10]; 18(1):[aprox.7 telas]. Disponivel em: http://www.scielo.br/scielo. php?script=sci_arttext\&pid=S1414-81452014000100075\&lng=en DOI: http://dx.doi.org/10.5935/1414-8145.20140011

15. Molina RCM, Higarashi IH, Marcon SS. Importance attributed to the social support network by mothers with children in an intensive care unit. Esc Anna Nery [Internet]. 2014 mar; [citado 2018 fev 11]; 18(1):[aprox.8 telas]. Disponível em: http://www.scielo.br/scielo. php?script=sci_arttext\&pid=S1414-81452014000100060\&lng=en DOI: http://dx.doi.org/10.5935/1414-8145.20140009

16. Brasil. Constituição da República Federativa do Brasil. Texto constitucional promulgado em 5 de outubro de 1988, com as alterações determinadas até a Emenda Constitucional no 90. Diário Oficial da União, Brasília (DF): Senado, 15 set 2015: Seção 1.

\footnotetext{
a Article extracted from doctoral thesis: The relative/companion weaving social networks during the child's hospitalization approved in the year of 2016 , in the Post-Graduation Program of the School of Nursing Anna Nery, Federal University of Rio de Janeiro, of the authorship of Rita de Cássia Melão de Morais, under the guidance of the Prof. Dr. Tania Vignuda de Souza.
} 